\title{
Kebijakan Berbasis Data: Analisis dan Prediksi Penyebaran COVID-19 di Jakarta dengan Metode Autoregressive Integrated Moving Average (ARIMA)
}

\author{
Hansen Wiguna ${ }^{1}$, Yudhistira Nugraha ${ }^{1,2, *}$, Farizah Rizka R. ${ }^{1}$, Ayu Andika ${ }^{1}$, Juan Intan Kanggrawan ${ }^{2}$, \\ Alex L. Suherman ${ }^{3}$ \\ ${ }^{1}$ Jakarta Smart City, Department of Communication, Informatics, and Statistics, Jakarta 10110, Indonesia \\ ${ }^{2}$ School of Informatics, Telkom University, Bandung 40257, Indonesia \\ ${ }^{3}$ Directorate of Research and Community Service, Telkom University, Bandung 40257, Indonesia
}

*Corresponding author: yudhistiranugraha@telkomuniversity.ac.id

\begin{abstract}
Abstrak-Data dan informasi merupakan bagian penting dalam pertimbangan mengambil keputusan terkait penanganan COVID-19. Data COVID-19 baik demografi maupun agregat di Provinsi DKI Jakarta diolah dan dianalisis untuk memberikan informasi mengenai situasi dan kondisi terkini terkait pandemi COVID-19 di Provinsi DKI Jakarta. Data COVID-19 tersebut juga dimanfaatkan untuk analisis prediktif untuk mengetahui perkiraan jumlah kasus COVID-19 di masa depan. Analisis prediktif yang digunakan dalam artikel ini adalah metode Autoregressive Integrated Moving Average (ARIMA). Model ARIMA merupakan salah satu metode forecasting hasil dari perluasan model Autoregressive Moving Average (ARMA) untuk data yang tidak stasioner. Analisis dan visualisasi data dilakukan menggunakan program Python dan Tableau dimana hasil analisis prediktif memperlihatkan tren kasus positif harian yang cenderung naik di kurun waktu 14 hari ke depan dari data yang digunakan. Hasil analisis ini dapat digunakan sebagai pertimbangan bagi pemerintah dalam mengambil kebijakan dan intervensi dalam penanganan COVID-19 di Jakarta, dan untuk masyarakat agar tetap melakukan tindakan preventif dalam mencegah kenaikan kasus, seperti mematuhi protokol kesehatan yang sudah ditetapkan oleh Pemerintah.
\end{abstract}

Kata Kunci-ARIMA, COVID-19, DKI Jakarta, Kebijakan Publik, Python, Tableau, Analisis Prediktif

\section{PENDAHULUAN}

Semenjak World Health Organization (WHO) menyatakan Coronavirus Disease 2019 atau COVID-19 sebagai pandemi, beberapa negara di dunia yang berpotensi besar terkena virus ini berusaha untuk menanggulangi penyebaran virus [1]. COVID-19 adalah penyakit baru yang dapat menyebabkan gangguan pernapasan dan radang paru. Penyakit ini disebabkan oleh infeksi Severe Acute Respiratory Syndrome Coronavirus 2 (SARS-CoV-2). Gejala klinis yang muncul beragam, mulai dari seperti gejala flu biasa (batuk, pilek, nyeri tenggorokan, nyeri otot, nyeri kepala) sampai yang berkomplikasi berat (pneumonia atau sepsis). Dari berbagai penelitian, metode penyebaran utama penyakit ini diduga adalah melalui droplet saluran pernapasan dan kontak dekat dengan penderita [2]. Droplet merupakan partikel kecil dari mulut penderita yang dapat mengandung virus penyakit, yang dihasilkan pada saat batuk, bersin, atau berbicara. Droplet dapat melewati sampai jarak tertentu (biasanya 1 meter). Droplet bisa menempel di pakaian atau benda di sekitar seseorang pada saat batuk atau bersin. Partikel droplet cukup besar sehingga tidak akan bertahan atau mengendap di udara dalam waktu yang lama. Namun, masyarakat diwajibkan untuk menggunakan alat pelindung wajah (seperti masker kain, face shield, dan lain-lain) yang menutupi hidung dan mulut untuk mencegah penyebaran droplet tersebut. Orang-orang yang terinfeksi mungkin memiliki gejala ringan, seperti demam, batuk, 
dan kesulitan bernapas. Pada beberapa kejadian juga ditemukan penderita COVID-19 bersifat simtomatik. Masa inkubasi diperkirakan antara 1-14 hari menurut standar WHO dan 2-14 hari oleh Centers for Disease Control and Prevention (CDC) [3].

Sifat COVID-19 yang dapat dengan mudah menyebar mengakibatkan Indonesia yang merupakan negara terpadat keempat di dunia diprediksi akan menghadapi ancaman besar terhadap pandemi ini, khususnya Jakarta sebagai Ibu Kota dan pusat perekonomian nasional telah menjadi pusat penyebaran virus di Indonesia [4] [5]. Persebaran kasus COVID-19 di Provinsi DKI Jakarta dari awal Maret 2020 terus mengalami peningkatan, baik dari yang sudah terkonfirmasi positif maupun yang meninggal karena virus COVID-19. Oleh karena itu, pemerintah perlu melakukan intervensi untuk mengurangi penyebaran COVID-19 di Provinsi DKI Jakarta.

Sejatinya peran data yang lebih utama adalah proyeksi dan prediksi, sehingga data dapat digunakan sebagai dasar untuk memprediksi keadaan di masa depan khususnya dalam proses pengambilan kebijakan seperti penetapan kondisi pembatasan sosial berskala besar (PSBB). Maka dari itu, diperlukan transparansi data sehingga masyarakat mengetahui secara persis situasi dan kondisi yang sedang dihadapi sesuai dengan ketentuan dalam Undang-Undang No. 14/2008 tentang Keterbukaan Informasi Publik. Data memiliki sifat yang sama yakni saling terkait satu sama lain (linked data) sehingga diperlukan aspek multidimensi atau melihat data dari berbagai sudut pandang. Data-data inilah yang dibutuhkan untuk kemudian digunakan sebagai dasar pengambilan kebijakan yang lebih baik untuk pemerintah [6]. Seperti yang ditulis dalam jurnal The Use of Big Data in The Public Policy Process: Paving The Way of Evidence Based Governance yang menunjukkan bahwa data dapat digunakan untuk meningkatkan efisiensi, efektivitas, transparansi pemerintah, dan penyedia layanan yang lebih baik berdasarkan pada peningkatan wawasan tentang kebutuhan dan tuntutan warga, serta pembuatan kebijakan yang lebih informatif [7] [8] [9].

Oleh karena pentingnya data dalam pengambil kebijakan (data-driven policy), tujuan penulisan artikel ini adalah untuk menganalisa dan memprediksi penyebaran kasus COVID-19 dalam mendukung Pemerintah Provinsi DKI Jakarta untuk melakukan kebijakan publik maupun intervensi untuk mengurangi penyebaran COVID-19 di Provinsi DKI Jakarta. Jakarta menjadi kasus yang menarik untuk dilakukan studi karena sebagai ibu kota dan pusat perekonomian nasional. Di samping itu Jakarta merupakan kota pertama di Indonesia yang menjadi pusat penyebaran kasus COVID-19.

Analisis dari data COVID-19 dapat memberikan informasi terkait kondisi pandemi COVID19 di Provinsi DKI Jakarta. Hasil analisis data melalui berbagai grafik visualisasi akan mempermudah masyarakat Jakarta untuk memahami informasi COVID-19 terkini yang dapat diakses melalui corona.jakarta.go.id. Analisis ini juga dapat digunakan sebagai bahan pertimbangan dalam mengambil keputusan atau membuat kebijakan bagi Pemerintah Provinsi DKI Jakarta dalam menekan penyebaran kasus COVID-19. Selain itu, hasil analisis prediktif kasus COVID-19 di Provinsi DKI Jakarta dapat dimanfaatkan sebagai salah satu informasi dalam upaya melakukan tindakan preventif atau pencegahan terhadap lonjakan jumlah kasus yang diprediksi akan semakin meningkat jika tidak ada intervensi langsung dari pemerintah.

Penelitian-penelitian sebelumnya sudah pernah dilakukan oleh Ram Kumar Singh, Meenu Rani, dkk tentang Prediksi Pandemi COVID-19 untuk Top 15 Negara Terdampak: Model Advanced ARIMA, dalam penelitian tersebut dijelaskan bahwa Model ARIMA dapat memberikan bobot pada masa lampau dan nilai kesalahan untuk mengoreksi prediksi model, sehingga lebih baik dari metode regresi ataupun metode eksponensial dasar lainnya (Singh, et al., 2020) [10]. Penelitian lain juga pernah dilakukan oleh Gaetano Perone yang membahas tentang Penyebaran dan Final Size Epidemi COVID-19 di Italia denga menggunakan model ARIMA. Alasan utama Gaetano Perone menggunakan model ini adalah mudah diatur dan disesuaikan serta dapat memberikan tren dasar (Perone, 2020) [11]. Penelitian serupa juga telah dilakukan Saleh I. Alzahrani, Ibrahim A. Aljamaan, dkk yang meneliti tentang Forecasting penyebaran COVID-19 di Saudi Arabia dengan beberapa metode forecasting yakni Autoregressive Model, Moving Average, gabungan keduanya (ARMA), dan ARIMA. Dari ke 
empat model tersebut didapatkan bahwa model ARIMA lebih baik dibanding dengan model lainnya (Alzahrani, Aljamaan, \& Al-Fakih, 2020) [12].

Adapun struktur penulisan artikel ini selanjutnya sebagai berikut. Bab 2 akan memberikan informasi terkait dataset dan metodologi yang digunakan dalam kajian ini. Bab 3 menampilkan hasil dan analisis dari prediksi penyebaran COVID-19 di Jakarta. Bab 4 mendiskusikan implikasi dari hasil analisis data dan interpretasi serta rekomendasi yang dihasilkan dari studi ini. Selanjutnya Bab 5 mengakhiri artikel ini dengan kesimpulan dan studi lanjutan.

\section{Dataset dan Metodologi}

Pengolahan data untuk analisis dan prediksi penyebaran kasus COVID-19 di Provinsi DKI Jakarta terdiri dari beberapa tahap. Tahap pertama yaitu mendapatkan data dari sumber data. Data utama berasal dari Dinas Kesehatan DKI Jakarta. Data ini berupa database yang digunakan oleh dinas kesehatan, puskesmas, dan rumah sakit. Data yang didapat merupakan format tabel dan diperbaharui setiap hari. Tahap kedua adalah pengolahan data oleh pihak Jakarta Smart City dan Dinas Cipta Karya, Tata Ruang dan Pertanahan. Tahap ketiga adalah proses preparasi dan pembersihan data. Dalam tahap ini, dipastikan tidak ada data berulang maupun tidak ada kondisi data yang inkonsisten. Akhirnya, tahap keempat adalah visualisasi data ke microsite corona.jakarta.go.id dan diperbarui setiap hari. Gambar 1 di bawah ini menunjukkan flow diagram proses pengolahan data:

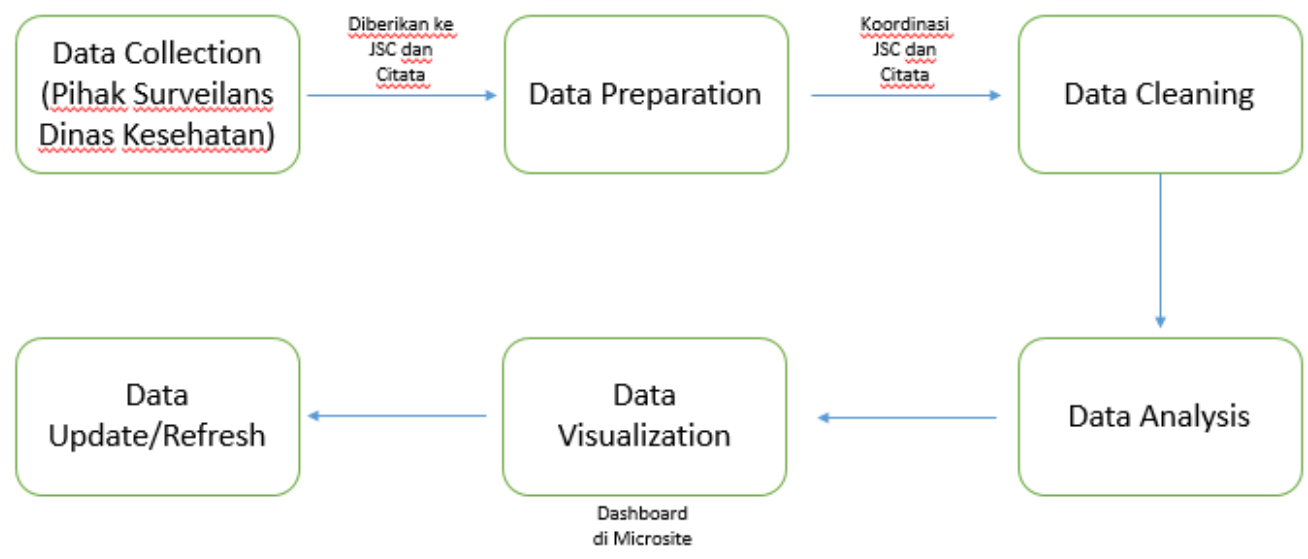

Gambar 1. Diagram Proses Pengolahan Data

Secara garis besar, pendekatan analisis bisa dibagi ke dalam dua kelompok. Pendekatan yang pertama adalah mengenai pola persebaran kronologis COVID-19 di Jakarta. Pendekatan yang kedua adalah terkait usaha prediksi COVID-19.

\section{A. Pola Persebaran Kronologis}

Dalam melihat pola persebaran kronologis, data yang digunakan adalah data yang diberikan oleh Dinas Kesehatan Provinsi DKI Jakarta. Data utama yang digunakan adalah data harian Pasien Dalam Pengawasan (PDP), Orang Dalam Pemantauan (ODP), dan positif yang tersebar di berbagai wilayah di DKI Jakarta. Melalui data ini, bisa dilihat fluktuasi atau perkembangan kondisi COVID-19, terutama dalam periode Maret- awal Juli 2020. Data tersebut akan dijabarkan berdasarkan urutan waktu (time series). 


\section{B. Prediksi COVID-19}

Selain visualisasi data, analisis lain yang dilakukan adalah analisis prediktif untuk kasus COVID-19 di Provinsi DKI Jakarta. Usaha melakukan prediksi pola COVID-19 adalah suatu hal yang kompleks [13]. Hal ini disebabkan oleh banyaknya faktor yang belum diketahui secara pasti dan masih dalam tahap eksplorasi atau pengembangan terkait COVID-19. West Churchman menggunakan terminologi "wicked problem" terkait fenomena semacam ini [14]. Meskipun demikian, berbagai institusi telah melakukan usaha-usaha prediksi terkait COVID-19. Berikut adalah beberapa contoh metode prediksi yang dilakukan: mechanistic transmission model (Imperial College London), SEIR model (Machachusetts Institute of Technology), statistical model (ETH Zurich).

Data yang digunakan yaitu data pertambahan kasus positif harian. Pada analisis ini, metode analisis prediktif yang digunakan adalah Autoregressive Integrated Moving Average atau ARIMA. ARIMA merupakan salah satu metode forecasting yang dikembangkan oleh George Box and Gwilym Jenkins pada tahun 1970 [15]. Model ARIMA merupakan perluasan dari model Autoregressive Moving Average (ARMA) ketika data tidak stasioner, yaitu dengan melakukan differencing pada data. Penerapan metode ARIMA untuk periode jangka pendek lebih akurat dibandingkan untuk peramalan periode jangka panjang [16]. Pada umumnya, nilai ramalan untuk periode yang panjang akan cenderung konstan.

Bentuk umum dari model autoregressive dinotasikan sebagai AR(p) sebagai berikut [15] :

$$
X_{t}=\varphi_{1} X_{\mathrm{t}-1}+\mathrm{k}+\varphi_{\mathrm{p}} \mathrm{X}_{\mathrm{t}-\mathrm{p}}+\mathrm{e}_{\mathrm{t}}
$$

dimana :

$X_{t}=$ nilai variabel pada waktu ke $t$

$\varphi i=$ koefisien autoregressive, $I=1,2,3, \ldots, \mathrm{p}$

$\mathrm{e}_{\mathrm{t}}=$ nilai galat pada waktu ke- $t$

Model Moving Average (MA) order $q$, dinotasikan menjadi $M A(q)$. Secara umum, model $M A(q)$ sebagai berikut:

$$
X_{t}=e_{t}-\theta_{1} e_{t-1}-k-\theta_{q} e_{t-q}
$$

dimana :

$\theta_{1}=$ parameter model moving average (MA)

et $-q=$ nilai kesalahan pada saat $t-q$

$q=$ order MA

\section{HASIL DAN ANALISA}

Berdasarkan metodologi yang dijelaskan sebelumnya, hasil yang diperoleh dalam artikel ini mencakup analisis data COVID-19 berdasarkan jenis kelamin, kelompok umur, hasil uji lab, dan kenaikan kasus harian beserta prediksinya.

Dari sudut pandang demografi, langkah awal adalah melakukan pembagian berdasarkan status: (i) (ODP) (ii) (PDP) (iii) Pasien Positif. Langkah selanjutnya adalah melakukan analisis lebih jauh berdasarkan distribusi jenis kelamin dan umur. Sejak awal mula merebaknya kasus COVID-19 di Jakarta pada bulan Maret 2020 sampai sekarang, rentang umur yang terjangkit 
positif COVID-19 konsisten di rentang umur 20-59 tahun seperti yang ditunjukkan pada Gambar 2 di bawah ini.
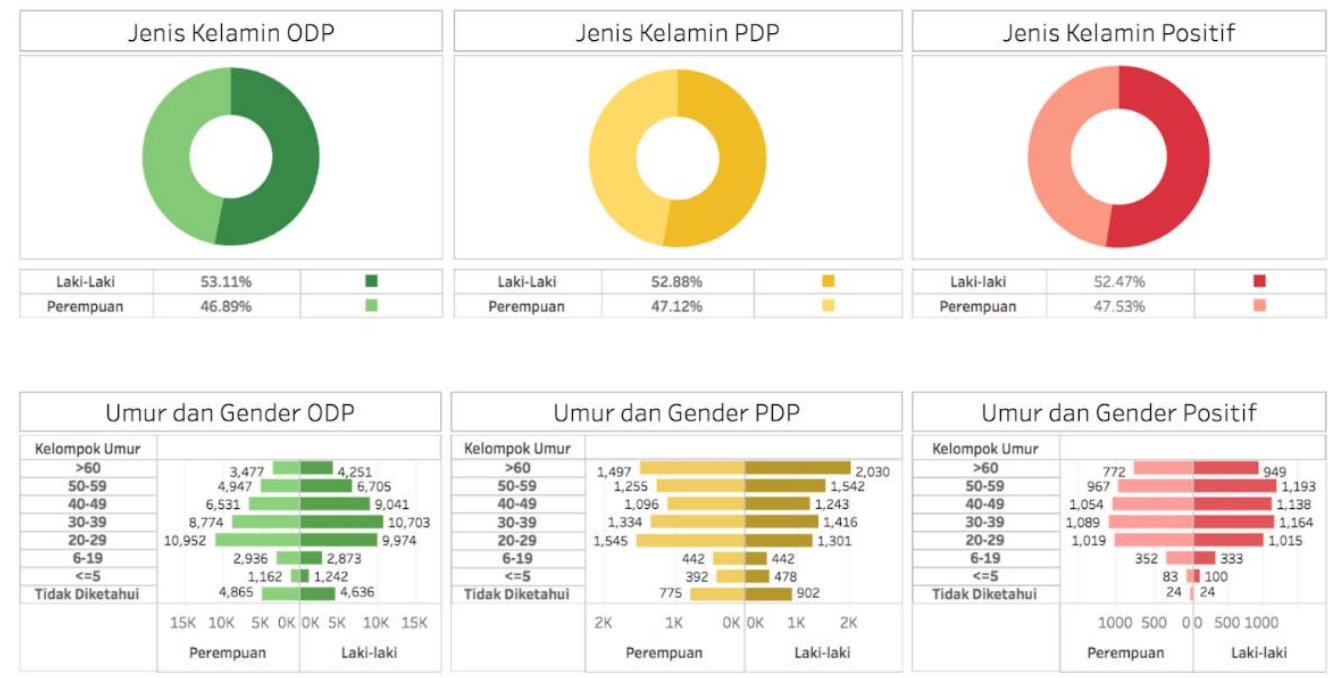

Gambar 2. Distribusi Jenis Kelamin dan Umur

Seiring bertambahnya usia seseorang, tubuh akan mengalami berbagai penurunan akibat proses penuaan. Mulai dari menurunnya produksi hormon, ketahanan kulit, massa otot, kepadatan tulang, hingga kekuatan dan fungsi organ-organ tubuh. Khususnya untuk orang yang berusia lebih lanjut, sistem imun sebagai pelindung tubuh pun tidak dapat bekerja secara maksimal layaknya usia muda. Untuk usia yang lebih muda antara 20-39 yang terpapar, ada kemungkinan orang dengan riwayat penyakit tertentu. Banyaknya tenaga medis usia muda yang menangani pasien yang memiliki resiko tertular paling besar pula.

Selanjutnya, analisis berdasarkan rentang waktu (time series) dilakukan terkait pola testing yang dilakukan. Dua variabel utama yang menjadi titik fokus adalah jumlah orang yang di-tes dan positivity rate kasus harian. Positivity rate adalah perbandingan antara orang yang dinyatakan positif COVID-19 dengan jumlah tes yang dilakukan. Hampir sama dengan pola di seluruh provinsi lain di Indonesia, banyaknya jumlah test baru meningkat secara signifikan di bulan April 2020, kemudian Juni 2020. Ada berbagai persiapan sarana dan prasarana yang diperlukan untuk dapat melakukan tes secara masif dan sistematis. Positivity rate untuk Jakarta melonjak dan berfluktuasi cukup tajam di bulan Maret 2020 sampai pertengahan April 2020, mencapai $>50 \%$. Positivity rate kemudian menurun dan relatif stabil $<10 \%$ semenjak pertengahan April 2020 sampai sekarang yang dapat dilihat pada Gambar 3. Salah satu kesimpulan yang bisa diambil dari grafik adalah kapasitas testing yang dilakukan DKI Jakarta merupakan hal yang baik dan terus ditingkatkan sehingga akhirnya mampu memenuhi standar yang ditentukan WHO. Referensi standar WHO positivity rate $<5 \%$. Positivity rate menjadi indikator yang dijadikan dasar apakah persebaran COVID-19 berkurang atau tidak, bukan berdasarkan jumlah kasus positif. Dengan memperhatikan hal ini, setiap daerah didorong untuk meningkatkan kapasitas testing. 


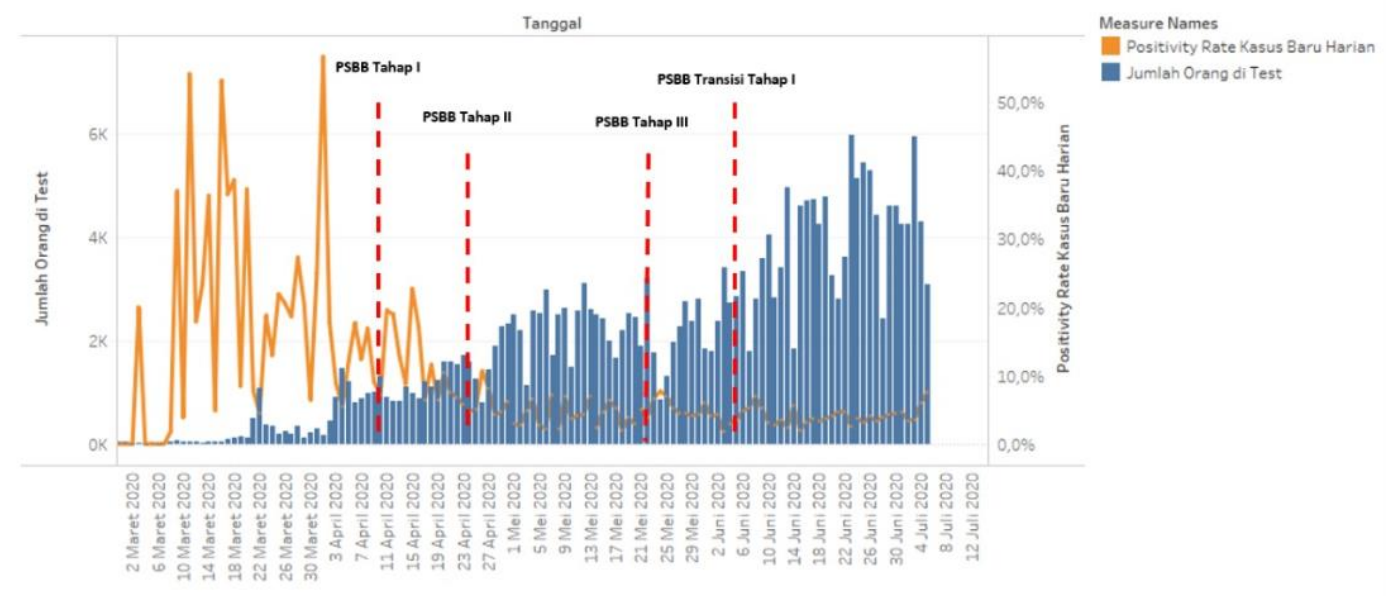

Gambar 3. DKI Jakarta Testing Trends

Pola pasien positif, sembuh, dan meninggal juga menunjukkan pola yang menarik yang dapat dilihat pada Gambar 4. Lonjakan pasien sembuh tercatat sangat tinggi pada tanggal 12 Mei 2020 (426 orang), 7 Juni 2020 (330 orang) dan 30 Juni (394 orang). Mengenai jumlah pasien positif, terjadi peningkatan gradual awal Maret sampai pertengahan April (16 April mencapai 223 orang). Kemudian jumlah positif relatif stabil. Peningkatan jumlah positif baru terjadi lagi di pertengahan Juni 2020 sampai sekarang. Jumlah pasien meninggal tercatat paling banyak pada awal sampai pertengahan April 2020 (pada 19 April 35 orang). Selain itu, secara garis besar, kasus sembuh harian semakin meningkat secara fluktuatif dibandingkan kasus meninggal harian yang stabil dan kasus positif harian yang relatif stabil. Apabila hal ini terus dipertahankan tentunya merupakan hal yang baik dan menandakan peran dari fasilitas kesehatan yang mengerjakan tugas dengan baik dalam merawat pasien-pasien COVID-19. Dalam kajian ini, belum ditelusuri secara lebih mendalam mengenai kaitan antara tren jumlah positif harian dan jumlah sembuh harian. Ada beberapa faktor yang mungkin memberikan kontribusi terhadap hal ini. Misalkan saja, jumlah positif harian yang cenderung stabil diakibatkan oleh penerapan pembatasan sosial (PSBB) yang dapat menghambat laju penambahan kasus baru. Jumlah pasien sembuh yang semakin meningkat bisa disebabkan oleh instansi, sarana, dan prasarana kesehatan di DKI Jakarta yang sudah semakin belajar dan tanggap dalam menangani pasien COVID-19.

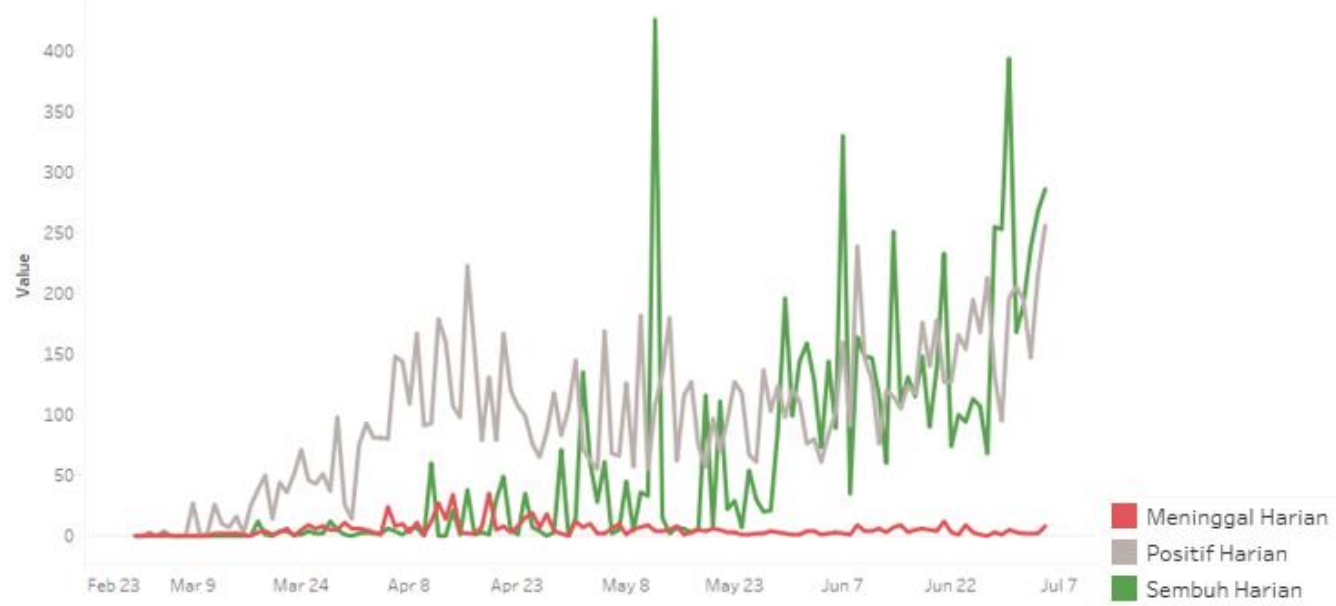

Gambar 4. Grafik Harian COVID-19 Jakarta 
Berikut adalah analisis prediktif data positif harian menggunakan metode ARIMA [17] [18]. Data diambil dari 1 Maret hingga 5 Juli 2020 dan memprediksi 14 hari ke depan yang dapat dilihat pada Gambar 5. Sebelumnya memastikan keakuratan prediksi, dilakukan perbandingan data prediksi dengan data aktual dimana didapatkan Mean Absolute Percentage Error (MAPE) sebesar 20,97\% dan Root Mean Squared Error (RMSE) sebesar 42,415. Berdasarkan standar ilmu statistik, persentase error bisa diterima tergantung konteks dan kondisi data ketika analisis prediksi itu digunakan. Dalam kondisi industri pada umumnya, persentase error di kisaran 5\% $10 \%$ bisa dikatakan normal/cukup baik. Dalam kondisi COVID-19, ada berbagai faktor yang menyebabkan analisis ini lebih menantang. Kondisi data, fluktuasi, basis data historis, dan kemungkinan yang akan terjadi ke depan masih sangat variatif. Sehingga lumrah jika persentase error untuk analisis COVID-19 ini lebih tinggi dari kondisi industri pada umumnya. Dari nilai MAPE yang didapat, kisaran nilai $20.97 \%$ bisa cukup diterima dalam konteks COVID-19. Meskipun demikian, ketika data dan pola COVID-19 semakin terlihat di waktu-waktu mendatang, persentase error diharapkan bisa bergerak ke kisaran 10\%-15\%.
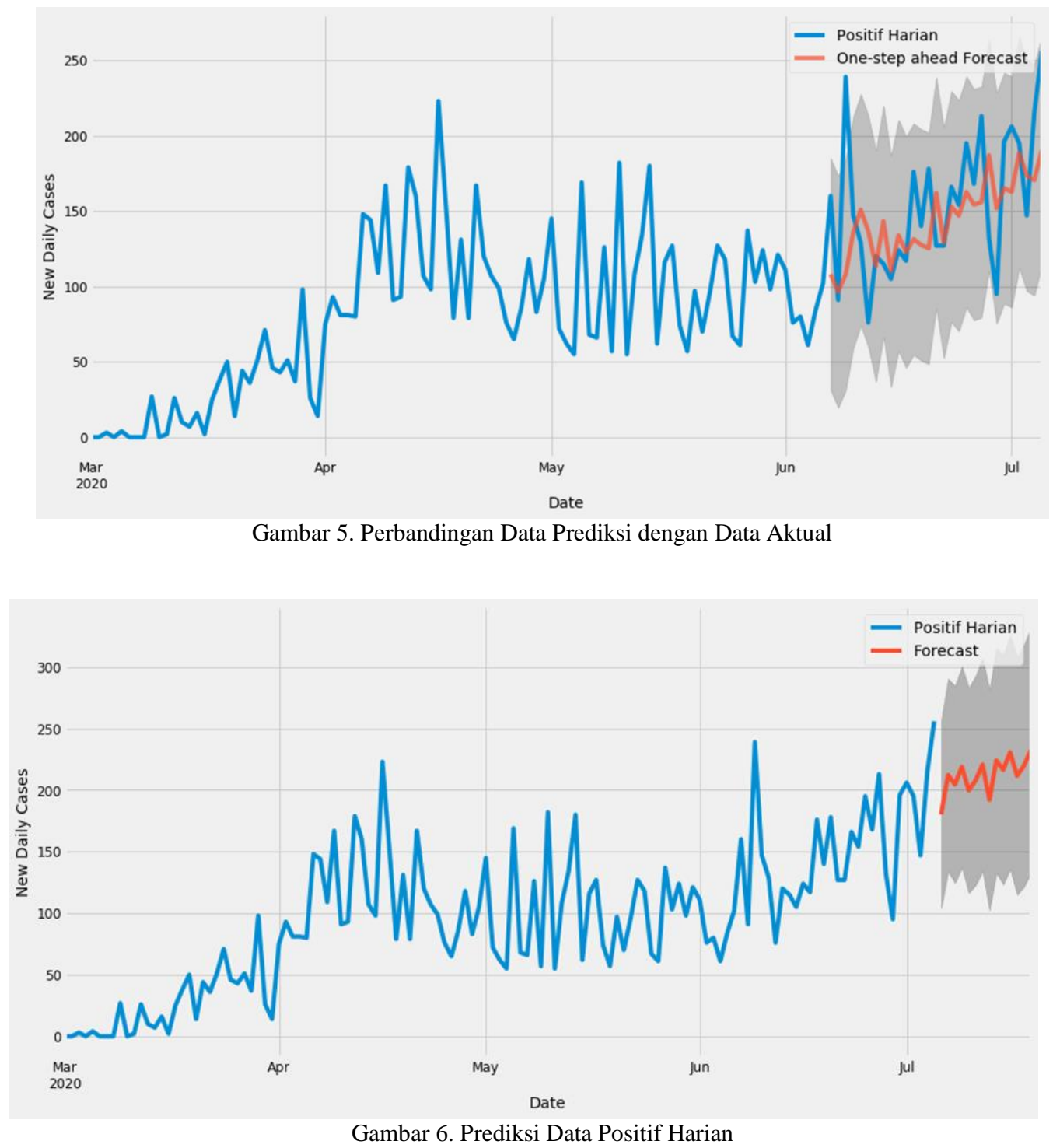

Secara umum, grafik COVID-19 akan membentuk "S-shape" ketika dilihat secara time series kumulatif, ataupun "bell-curve" jika dilihat dalam jumlah positif harian yang dapat dilihat pada Gambar 6. Secara sederhana, yang penting untuk dilihat adalah grafik puncak dari suatu "bellcurve". Dari pola puncak kurva tersebut, akan bisa dilihat pola penurunan kasus COVID-19 
harian dan bisa membantu dalam melakukan estimasi berakhirnya COVID-19 (Luo, 2020). Secara logis, ketika puncak kurva bisa dipastikan, pola penurunan setelahnya akan lebih mudah diestimasi. Hanya saja, dalam konteks COVID-19, bisa terjadi COVID-19 gelombang kedua, ataupun lonjakan lebih signifikan di waktu ke depan dibandingkan dengan angka kasus yang dianggap sebagai puncak kurva. Pola dari "bell-curve" COVID-19 ini secara umum tidak berbentuk simetris. Usaha prediktif yang dilakukan akan bermanfaat dalam menentukan kemungkinan titik puncak dari kasus COVID-19 yang terjadi. Walau sepertinya yang dijelaskan sebelumnya, masih banyak faktor yang mungkin memengaruhi pola yang akan terjadi, misalkan saja kemungkinan adanya gelombang kedua dari COVID-19 ini. Jika skenario ini terjadi, maka akan terjadi pola puncak, melandai, dan kemudian membentuk puncak baru yang bisa lebih tinggi dari puncak yang pertama. Dalam mengakomodasi skenario ini, pendekatan ARIMA bisa mengalami keterbatasan. Perlu dipikirkan usaha/riset lanjutan yang dapat mengantisipasi dan memberikan analisis yang lebih menggambarkan kemungkinan skenario ini.

\section{DISKUSI}

Dalam bagian ini, pembahasan kajian ini akan dibandingkan dengan berbagai studi kasus, riset, dan analisa serupa yang sudah dikerjakan di provinsi lain, maupun kota/negara lain. Melalui perbandingan ini, dapat dilihat apakah hasil analisis dalam kajian sudah sesuai dengan konteks usaha prediksi COVID-19 yang terjadi di tempat lain. Selain itu, akan dijelaskan pula berbagai implikasi terhadap berbagai pihak, baik itu pemerintah, industri/swasta, lembaga riset, dan masyarakat pada umumnya. Melalui penjelasan implikasi ini, diharapkan berbagai lapisan masyarakat di DKI Jakarta juga dapat mengambil bagian sekaligus mendapatkan manfaat dari kajian ini.

Usaha yang dilakukan dalam kajian ini tentunya masih dalam tahap awal dan bisa terus dikembangkan lebih jauh. Sudah ada beberapa riset terkait usaha prediksi COVID-19 dengan berbagai pendekatan. Mengenai metode prediksi, berikut adalah beberapa contoh yang dilakukan: mechanistic transmission model (Imperial College London), SEIR model (Machachusetts Institute of Technology), statistical model (ETH Zurich). Salah satu kajian yang kerap menjadi pembahasan adalah pendekatan dan model yang dilakukan oleh University of Oxford dan Imperial College London. Pendekatan yang dilakukan cukup berbeda, yakni pendekatan deterministik dan pendekatan stochastic. Perbandingan dari dua pendekatan ini menuai banyak diskusi di kalangan riset dan akademisi. Jika ditelusuri secara lebih mendasar, pertanyaan riset yang diajukan juga cukup berbeda. University of Oxford menekankan mengenai kondisi persebaran COVID-19. Sedangkan Imperial College London lebih menelusuri bagaimana mengubah tren dari COVID-19 dan dapat melandaikan kurva kasus positif COVID19. Dua kerangka dan model tersebut dinilai baik dan matang dalam desain metodologi mereka. Meskipun demikian, implikasi dan rekomendasi yang dihasilkan dari riset ini bisa berbeda. Sedikit belajar dari fenomena ini, kajian riset ini perlu dipertajam lagi mengenai pertanyaan dasar, asumsi, model, dan tujuan spesifik yang diharapkan. Penelusuran dari berbagai model yang dilakukan di berbagai negara dan instansi bisa menjadi aspek pembelajaran untuk konteks penerapan di Indonesia, khususnya Jakarta. Menerjemahkan hasil prediksi ke dalam keputusan kebijakan nyata juga memerlukan perhatian khusus.

Dari hasil analisis dan prediksi data COVID-19 Provinsi DKI Jakarta ini tentunya banyak memberikan manfaat bagi masyarakat maupun kalangan akademisi. Dengan pembuatan website resmi pemerintah yang memberikan data secara transparan dan resmi ini diharapkan mampu memberikan rasa aman dan percaya dari masyarakat. Melalui analisis data dan prediksi ini diharapkan mampu memberikan pertimbangan rekomendasi kebijakan yang diambil oleh Pemprov DKI Jakarta. Sedapat mungkin Pemprov DKI juga mengikuti standard World Health Organization dalam memantau situasi COVID-19 ini. Misalkan saja penggunaan variabel positivity rate yang digunakan untuk memantau perkembangan COVID-19 di Jakarta. Berbagai analisis lanjutan bisa dihasilkan setelah adanya publikasi data yang transparan dan dapat 
dipercaya dari pihak pemerintah. Banyak kalangan akademisi, professional, institusi, private sector, hingga telco data company yang memanfaatkan data dan momentum masa pandemi ini untuk berkolaborasi dan berkontribusi dengan Pemprov DKI Jakarta. Berbagai bentuk kolaborasi dan bantuan dari berbagai pihak ini bisa membantu di berbagai tahapan alur baik dari pengumpulan data, tracing pasien, pengaruh kebijakan ke mobilitas transportasi maupun peserta didik, hingga kualitas udara dan efek gas rumah kaca.

\section{KESIMPULAN DAN STUDI LANJUTAN}

Kajian ini bertujuan untuk melakukan analisis data demografi COVID-19 dan melakukan usaha prediksi mendasar dengan menggunakan metode ARIMA. Sejak awal mula merebaknya kasus COVID-19 di Jakarta pada bulan Maret 2020 sampai sekarang, rentang umur yang terjangkit positif COVID-19 konsisten di rentang umur 20-59 tahun. Dengan menggunakan metode ARIMA, diperoleh Mean Absolute Percentage Error (MAPE) sebesar 20,97\%. Persentase error ini memang lebih tinggi dibandingkan standar industri pada umumnya. Namun dengan mempertimbangkan kondisi COVID-19 yang banyak fluktuasi dan ketidakpastian, persentase error ini bisa diterima. Dalam waktu-waktu ke depan, diharapkan usaha prediksi ini bisa menghasilkan akurasi yang lebih baik dan rentang persentase error yang lebih kecil.

Kajian ini tentunya masih memerlukan pengembangan lebih jauh, terutama dalam mencakup kemungkinan adanya gelombang kedua dari COVID-19, atau tren kasus positif yang terus memuncak di waktu ke depan. Pendekatan saat ini berusaha memberikan estimasi titik puncak COVID-19, untuk kemudian melakukan prediksi kapan COVID-19 bisa lebih berkurang. Dalam usaha-usaha ke depan, bisa dipertimbangkan berbagai teknik dan metode forecasting yang bisa lebih matang, misalkan saja double exponential smoothing, autoregressive moving average, autoregressive moving average with exogenous inputs, atau seasonal naive approach.

Spesifik bagi pemerintah selaku pengambil kebijakan, ada beberapa opsi/pertimbangan yang bisa diambil berdasarkan metode analisa yang dilakukan oleh para ahli dan akademisi. Selain mempelajari dan mempertimbangkan berbagai metode riset terkini terkait COVID-19, adalah penting untuk selalu membandingkannya dengan situasi yang terjadi di lapangan. Dengan demikian, berbagai asumsi yang ada dalam tatanan riset/kajian bisa selalu dibandingkan dengan kondisi nyata yang terjadi. Penyesuaian dan pembaharuan kebijakan terkait COVID-19 juga bisa terus dilakukan dengan tujuan membawa dampak positif yang nyata bagi masyarakat.

\section{REFERENSI}

[1] Zahrotunnimah, "Langkah Taktis Pemerintah dalam Pencegahan Penyebaran Virus Corona Covid-19 di Indonesia," Jurnal Sosial \& Budaya Syar'i, vol. 7, no. 3, pp. 247-260, 2020.

[2] Seto WH, Tsang D, Yung RW, et al. "Effectiveness of Precautions Against Droplets and Contact in Prevention of Nosocomial Transmission of Severe Acute Respiratory Syndrome (SARS)," Lancet, vol. 361, no. 9368, pp. 1519-1520, 2003.

[3] Pemerintah Provinsi DKI Jakarta, "Jakarta Tanggap COVID-19," Pemerintah Provinsi DKI Jakarta, 2020. [Online]. Available: https://corona.jakarta.go.id/id. [Diakses 8 July 2020].

[4] F. Fadly dan E. Sari, "An Approach to Measure the Death Impact of Covid-19 in Jakarta using Autoregressive Integrated Moving Average (ARIMA)," Unnes Journal of Public Health, vol. 9, no. 2, 2020.

[5] United States Census Bureau, "U.S. Census Bureau Current Population," 1 July 2020. [Online]. Available: https://www.census.gov/popclock/print.php?component=counter. [Diakses 8 July 2020].

[6] A. Kunaefi, Detik.com, 17 April 2020. [Online]. Available: https://news.detik.com/kolom/d-4980560/pandemi-data-dan-kebijakan-publik. [Diakses 8 July 2020]. 
[7] J. Studinka dan A. A. Guenduez, "The Use of Big Data in the Public Policy Process: Paving the Way for EvidenceBased Governance," EGPA Conference 2018, 2018.

[8] G. Ding, X. Li, Y. Shen and J. Fan, "Brief Analysis of The ARIMA Model on The COVID-19 in Italy," medRxiv, 2020.

[9] Q. Yang, J. Wang, H. Ma and X. Wang, "Research on COVID-19 based on ARIMA Model- Taking Hubei, China as an example to see the epidemic in Italy," Elsevier, p. 4, 2020.

[10] R. K. Singh, M. Rani, A. S. Bhagavathula, A. J. R. Morales, H. Kalita, C. Nanda, S. Sharma, Y. D. Sharma, A. A. Rabaan, J. Rahmani and P. Kumar, "Prediction of the COVID-19 Pandemic for the Top 15 Affected Countries: Advanced Autoregressive Integrated Moving Average (ARIMA) Model," Jorunal of Medical Internet Research (JMIR), vol. 6, no. 2, p. e19115, 2020.

[11] G. Perone, "An ARIMA Model to Forecast the Spread and the Final Size of COVID-2019 Epidemic in Italy," Social Science Research Network (SSRN), 2020.

[12] S. I. Alzahrani, I. A. Aljamaan and E. A. Al-Fakih, "Forecasting the spread of the COVID19 pandemic in Saudi Arabia using ARIMA prediction model under current public health interventions," Journal of Infection and Public Health, vol. 13, pp. 914-919, 2020.

[13] "Data-Driven Innovation Lab," Singapore University of Technology and Design (SUTD), 11 May 2020. [Online]. Available: https://ddi.sutd.edu.sg/. [Diakses 8 July 2020].

[14] C. W. Churchman, "Wicked Problems," Management Science, vol. 14, pp. B141-B142, 1967.

[15] S. G. Makridakis, S. C. Wheelwright dan R. J. Hyndman, Forecasting: Methods and Application, 3rd penyunt., New Jersey: John Wiley \& Sons, Inc., 1998.

[16] H. Tusyakdiah, Medium, [Online]. Available: https://medium.com/@halima23121998/penerapan-metode-auto-regressive-integratedmoving-average-arima-pada-peramalan-harga-bitcoin-77558605eaf5. [Diakses 8 July 2020].

[17] D. Benvenuto, M. Giovanetti, L. Vassallo, S. Angeletti and M. Ciccozzi, "Application of the ARIMA Model on The COVID-2019 Epidemic Dataset," Elsevier, vol. 29, no. 40, p. 1053, 2020.

[18] L. Bayyurt and B. Bayyurt, "Forecasting of COVID-19 Cases and Deaths Using ARIMA Models," medRxiv, 2020. 